\title{
IMPLEMENTASI DISCOVERY LEARNING DENGAN PRAKTIKUM KINGDOM PLANTAE UNTUK MELATIH KETERAMPILAN PROSES DI MA UNGGULAN KH. Abd. WAHAB HASBULLOH TAMBAKBERAS JOMBANG
}

\author{
Ospa Pea Yuanita Meishanti ${ }^{1}$, Fatikhatun Nikmatus Sholihah ${ }^{2}$, Nadia Septi Ulan Dari ${ }^{3}$ \\ 1,2Universitas KH. A. Wahab Hasbullah; Jl. Garuda No.09 Tambakberas Jombang \\ ${ }^{3}$ Program Studi Pendidikan Biologi, FIP, Universitas KH. A. Wahab Hasbullah \\ e-mail: ${ }^{* 1}$ ospapea@unwaha.ac.id
}

\begin{abstract}
Abstrak
Kurikulum 2013 mengutamakan pendidikan yang berpusat pada peserta didik. Peserta didik harus lebih aktif dalam mengembangkan kompetensi yang dimilikinya. Pengembangan kompetensi dapat meliputi sikap, pengetahuan maupun keterampilan peserta didik, salah satu keterampilan yang dimaksud adalah keterampilan proses peserta didik. Keterampilan proses peserta didik di kelas X MIPA 2 pada pembelajaran biologi di MA Unggulan KH.Abd. Wahab Hasbullah Tambak Beras Jombang belum pernah dinilai. Penilaian dapat dilakukan melalui kinerja dalam kegiatan praktikum. Penelitian ini bertujuan untuk mengetahui pengaruh model discoveri learning melalui pembelajaran praktikum kingdom plantae terhadap keterampilan proses peserta didik di MA Unggulan KH. Abdul Wahab Hasbullah Tambak Beras Jombang. Metode penelitian jenis penelitian yang digunakan pada penelitian ini adalah penelitian kuantitatif dengan desain Pre-Eksperimen Design dengan bentuk desain One-group pretest-posttest design. Pretest diberikan sebelum adanya perlakuan dan posttest diberikan setelah adanya perlakuan. Sampel yang digunakan pada penelitian ini adalah peserta didik kelas X MIPA 2 MA Unggulan KH. Abdul Wahab Hasbullah Tambak Beras Jombang dengan jumlah 33 peserta didik. Pengumpulan data dilakukan melalui wawancara, observasi, dan angket kinerja keterampilan proses peserta didik. Instrumen yang digunakan antara lain: panduan wawancara, perangkat pembelajaran, lembar keterlaksanaan pembelajaran, dan lembar penilaian keterampilan proses peserta didik. Data yang diperoleh selanjutnya dianalisis secara statistik menggunakan rumus uji korelasi product moment. Hasil analisis uji korelasi product moment diperoleh nilai rhitung $=0,801$ dan rtabel pada taraf signifikansi 5\% $\alpha=$ 0,05 sebesar 0,345, maka diperoleh rhitung > rtabel dengan demikian Ha diterima dan Ho ditolak, data tersebut menunjukkan adanya pengaruh yang signifikan pada implementasi model discovery learning dengan praktikum kingdom plantae terhadap keterampilan proses pesera didik di MA Unggulan KH. Abdul Wahab Hasbullah Tambak Beras Jombang.
\end{abstract}

Kata kunci-Discovery Learning, Keterampilan Proses, Praktikum,.

\section{PENDAHULUAN}

Permendikbud Nomor 36 Tahun 2018 tentang Perubahan Atas Peraturan Menteri Pendidikan dan Kebudayaan Nomor 59 Tahun 2014 tentang Kurikulum 2013 Sekolah Menengah Atas/Madrasah Aliyah, menjelaskan tentang karakteristik dari Kurikulum 2013 yaitu mengembangkan sikap, pengetahuan, dan keterampilan serta menerapkannya dalam berbagai situasi di sekolah dan masyarakat. Kurikulum 2013 mengutamakan pendidikan yang berpusat pada peserta didik (student-centered).

Peserta didik harus lebih aktif dalam mengembangkan kompetensi yang dimilikinya. Guru juga memiliki peran yang penting dalam mengembangkan kompetensi yang dimiliki peserta didik. Pengembangan kompetensi dapat meliputi sikap, pengetahuan maupun keterampilan peserta didik, salah satu keterampilan yang dimaksud adalah keterampilan proses.

Keterampilan proses adalah cara kerja, cara berpikir dan cara memecahkan suatu masalah; meliputi kegiatan mengumpulkan data, menghubungkan fakta satu dengan yang lain, mengimplementasikan data dan menarik kesimpulan. Keterampilan proses ini membantu peserta didik untuk mengikuti langkah-langkah kerja para ilmuwan (metode ilmiah) melalui penekanan dalam proses pembelajaran [1]. Keterampilan proses peserta didik perlu dilatih dan dikembangkan dalam pembelajaran. Pemahaman konsep peserta didik akan meningkat seiring dengan proses pembelajaran yang mengedepankan keterampilan proses di dalamnya. Keterampilan proses peserta didik dapat dilatih melalui penerapan model pembelajaran yang melibatkan peserta didik secara aktif dalam mendapatkan pengetahuan, misalnya melalui kegiatan mengamati atau observasi, mengelompokkan atau klasifikasi, menafsirkan atau interprestasi, meramalkan atau memprediksi, 
berhipotesis, merencanakan percobaan atau penelitian dan berkomunikasi [2]. Salah satu model pembelajaran yang dapat menjadi alternatif adalah model discovery learning.

Discovery learning adalah suatu rangkaian kegiatan pembelajaran yang melibatkan secara maksimal seluruh kemampuan peserta didik untuk mencari dan menyelidiki secara sistematis, kritis, dan logis sehingga mereka dapat menemukan sendiri pengetahuan, sikap dan keterampilan sebagai wujud adanya perubahan perilaku [3]. Discovery learning mampu mengatur pengajaran sedemikian rupa sehingga peserta didik memperoleh pengetahuan baru dengan menemukan sendiri [4]. Kegiatan belajar mengajar peserta didik dapat didukung dengan adanya praktikum, misalnya praktikum mengamati tumbuhan seperti tumbuhan lumut, tumbuhan paku dan tumbuhan berbiji. Kegiatan praktikum akan membantu peserta didik untuk menemukan konsep secara mandiri dengan mempraktikkan teori yang telah dipelajari selama poses pembelajaran [5]. Berikut ini adalah prosedur pelaksanaan model discovery learning [6] :

a. Stimulation (stimulasi/pemberian rangsangan)

Guru memberikan stimulan, untuk diamati peserta didik agar mendapat pengalaman belajar mengamati pengetahuan konseptual melalui kegiatan membaca, mengamati situasi atau melihat gambar.

b. Problem statement (pernyataan/identifikasi masalah)

Peserta didik diberikan pengalaman untuk menanya, mencari informasi, dan merumuskan masalah.

c. Data collection (pengumpulan data)

Peserta didik mencari dan mengumpulkan data/informasi yang dapat digunakan untuk menemukan solusi pemecahan masalah yang dihadapi.

d. Data processing (pengolahan data)

Peserta didik mencoba dan mengeksplorasi kemampuan pengetahuan konseptualnya untuk diaplikasikan pada kehidupan nyata, sehingga kegiatan ini juga akan melatih keterampilan berfikir logis dan aplikasi.

e. Verification (menguji hasil)

Peserta didik mengecek kebenaran atau keabsahan hasil pengolahan data melalui berbagai kegiatan, atau mencari sumber yang relevan baik dari buku atau media, serta mengasosiasikannya sehingga menjadi suatu kesimpulan.

f. Generalization (menyimpulkan)

Peserta didik digiring untuk menggeneralisasikan hasil kesimpulannya pada suatu kejadian atau permasalahan yang serupa, sehingga kegiatan ini juga dapat melatih pengetahuan metakognisi peserta didik.

Hasil wawancara dan angket analisis kebutuhan dengan guru biologi di MA Unggulan KH.Abd. Wahab Hasbullah pada bulan desember tahun 2019 menunjukkan bahwa desain ruang kelas yang terbuka dan jumlah peserta didik 33 orang menyebabkan guru kesulitan untuk menciptakan proses pembelajaran yang dapat melatih keterampilan proses peserta didik. Selain itu, guru belum pernah melakukan penilaian terhadap keterampilan proses peserta didik. Namun, guru telah memberikan kegiatan praktikum kepada peserta didik ketika mempelajari materi plantae. Respon peserta didik cukup antusias ketika pelaksanaan praktikum, sebagian besar peserta didik berpartisipasi aktif dibandingkan saat pembelajaran teori. Adapun model pembelajaran yang digunakan guru adalah CTL (contextual teaching and learning) dan belum pernah menggunakan model discovery learning.

Permasalahan yang terjadi adalah keterampilan proses peserta didik diketahui sehingga belum dapat dikembangkan. Keterampilan proses peserta didik perlu diidentifikasi dan dilakukan upaya melatihnya. Solusi yang ditawarkan untuk melatih keterampilan proses peserta didik adalah menggunakan model pembelajaran yang dapat mengaktifkan peserta didik dalam kegiatan pembelajaran sehingga terjadi interaksi antara guru dengan peserta didik, peserta didik dengan peserta didik dan peserta didik dengan sumber maupun media belajar. Salah satu model pembelajaran dapat digunakan adalah model pembelajaran discovery learning [7].

Penelitian sebelumnya yang dilakukan oleh [8] menunjukkan bahwa keterampilan proses sains peserta didik meningkat setelah diterapkan model guided discovery learning. Penelitian yang dilakukan oleh [9] bahwa model discovery learning berpengaruh terhadap keterampilan proses sains peserta didik pada materi larutan asam dan basa di kelas XI MAN 2 Aceh Utara, dan sebanyak 90,74\% peserta didik sangat setuju terhadap penggunaan model discovery learning. [10] melakukan penelitian yang menunjukkan pembelajaran berbasis praktikum mampu meningkatkan keterampilan proses sains peserta didik pada sub materi enzim.

Berdasarkan latar belakang masalah, peneliti tertarik untuk melakukan penelitian yang berjudul "Implementasi Discovery Learning dengan Praktikum kingdom Plantae untuk Melatih Keterampilan Proses Peserta Didik di MA Unggulan KH.Abd. Hasbulloh Tambak Beras Jombang". 
Jurnal Biologi dan Pembelajarannya, Vol 7 No 2, Oktober 2020. Pp: 36-43

e-ISSN: $2406-8659$

Tujuan dilakukannya penelitian ini adalah untuk mengetahui pengaruh model discovery learning dengan praktikum Kingdom Plantae terhadap keterampilan proses peserta didik kelas X MIPA 2 MA Unggulan KH.Abd. Wahab Hasbullah TambakBeras Jombang.

Manfaat penelitian ini bagi peneliti dengan menambah pengalaman dan pengetahuan dalam mengajar dengan terjun langsung ke lapangan dan memberikan pengalaman belajar yang menumbuhkan kemampuan dan keterampilan meneliti. Bagi sekolah memberikan bahan pertimbangan bagi sekolah untuk mengambil kebijakan yang berkaitan tentang model pembelajaran yang dapat mendukung keterampilan proses peserta didik. Bagi guru memberikan tambahan pengetahuan guru mengenai penilaian keterampilan proses dengan menggunakan model pembelajaran discovery learning. Sedangkan bagi peserta didik meningkatkan semangat belajar dan pemahaman peserta didik dengan mengamati tumbuhan secara langsung.

\section{METODE PENELITIAN}

Rancangan pada penelitian ini menggunakan penelitian kuantitatif, sedangkan jenis penelitian yang digunakan adalah penelitian Pre-Eksperimen Design, karena desain ini belum merupakan eksperimen sungguhsungguh, karena masih terdapat variabel dependen, jadi hasil eksperimen yang merupakan variabel dependen itu bukan semata-mata dipengaruhi oleh variabel independen. Hal ini dapat terjadi, karena tidak adanya variabel kontrol, dan sampel tidak dipilih secara random. Penelitian menggunakan One-group pretest-posttest design (Gambar 3.1). Pretest diberikan sebelum adanya perlakuan dan posttest diberikan setelah adanya perlakuan. Dengan demikian hasil perlakuan dapat diketahui lebih akurat karena dapat membandingkan dengan keadaan sebelum diberi perlakuan [11].

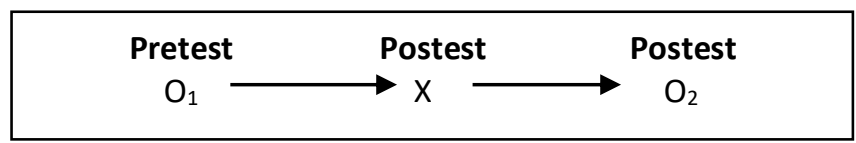

Gambar 3.1. Desain One-group pretest-posttest (Sugiyono, 2018)

Keterangan :

$\mathrm{X}=$ Perlakuan dengan menerapkan media spesimen tumbuhan (treatment)

$\mathrm{O}_{1}=$ Hasil nilai pretest (sebelum diberi perlakuan)

$\mathrm{O}_{2}=$ Hasil nilai posttest (setelah diberi perlakuan)

Populasi dalam penelitian ini seluruh pesera didik kelas $X$ MIPA. Sampel yang digunakan dalam penelitian ini ialah peserta didik kelas X MIPA 2 yang berjumlah 33 . Teknik pengambilan sampel dalam penelitian ini adalah dengan Purposive Sampling, atau cara penentuan sampel dengan

pertimbangan tertentu. Alasan digunakan purposive sampling karena peneliti hanya bisa menggunakan satu kelas dari dua kelas X MIPA di MA unggulan KH. Abd. Wahab Hasbullah. Peneliti mengambil kelas X MIPA 2 sebagai sampel karena dilihat dari jumlah peserta didik lebih banyak dan dilihat dari absen peserta didik kelas $X$ MIPA lebih aktif dan rajin masuk sekolah.

Adapun langkah-langkah dari kedua tahap tersebut yaitu sebagai berikut:

1. Prapenelitian

a. Membuat surat izin penelitian pendahuluan untuk observasi ke sekolah.

b. Mengadakan observasi ke sekolah tempat diadakannya penelitian, untuk mendapatkan informasi tentang kendala apa saja dalam proses pembelajaran, dan keadaan kelas yang diteliti.

c. Menetapkan sampel penelitian untuk kelas eksperimen dan kendala apa saja yang terdapat di sekolah tersebut.

d. Menyusun perangkat pembelajaran yang terdiri dari silabus, rencana pelaksanaan pembelajaran (RPP), dan lembar kerja praktikum (LKPD).

e. Membuat instrumen penelitian berupa angket keterampilan proses. Angket dimodifikasi dari Asti kurniawati. Dan membuat lembar angket keterlaksanaan pembelajaran.

2. Pelaksanaan Penelitian : Penelitian ini dilakukan 2 kali pertemuan dengan durasi jam pelajaran 95 menit.

a. Pertemukan ke-1 pretest peserta didik melakukan praktikum mandiri tanpa saya bimbing (diambil nilainya sebagai nilai pretest).

b. Pertemuan ke-2 posttest peserta didik melakukan praktikum dengan saya bimbing menggunakan model pembelajaran discovey learning (diambil nilainya sebagai nilai posttest).

c. Membentuk kelompok praktikum yang terdiri dari 8 kelompok tiap kelompok terdiri dari 5 peserta didik, tiap kelompok mengamati tumbuhan yang berbeda-beda, dan membagikan lembar kerja praktikum (LKP) kepada tiap kelompok. 
Jurnal Biologi dan Pembelajarannya, Vol 7 No 2, Oktober 2020. Pp: 36-43

e-ISSN: $2406-8659$

d. Peserta didik melakukan kegiatan praktikum.

e. Kemampuan keterampilan proses peserta didik dinilai dengan lembar penilaian keterampilan proses.

f. Penilai adalah peneliti dan pembantu peneliti hasil penilaian dianalisis secara kuantitatif.

g. Pembantu peneliti telah dilatih untuk melakukan penilaian keterampilan proses peserta didik

Teknik analisis data dilakukan dengan menggunakan analisis deskriptif kuantitatif. Data dideskripsikan dalam bentuk persentase dan dijelaskan menggunakan kalimat penjelasan secara kualitatif.

\section{Analisis Lembar Keterlaksanaan Pembelajaran}

Hasil pengamatan keterlaksanaan pembelajaran dianalisis dengan menggunakan analisis deskriptif kuantitatif dengan cara menghitung hasil pengamatan (diamati oleh observer) berdasarkan nilai rata-rata tiap bagian untuk tiap-tiap rencana pelaksanaan pembelajaran. Lembar keterlaksanaan pembelajaran dapat dihitung dengan rumus:

$$
\text { Nilai }=\frac{\text { Jumlah skor yang diperoleh }}{\text { Jumlah skor maksimal }} \times 100 \%
$$

Tabel 3.1 Kriteria Keterlaksanaan Pembelajaran

\begin{tabular}{ll}
\hline Rentang & Kriteria \\
\hline $0-40$ & Tidak baik \\
\hline $41-60$ & Kurang baik \\
\hline $61-80$ & Cukup baik \\
\hline $81-100$ & Baik \\
\hline
\end{tabular}

Sumber: Avianti\& Yonata, 2015

\section{Analisis Angket Keterampilan Proses}

Penelitian ini penilaian keterampilan bersumber dari hasil penilaian melalui teknik observasi yang dilakukan pengamat (guru). Instrumen yang digunakan berupa skala linkert yang disertai rubrik. Nilai keterampilan proses dari peserta didik dihitung dengan rumus:

$$
\text { Nilai }=\frac{\text { Jumlah skor yang diperoleh }}{\text { Jumlah skor maksimal }} \times 100 \%
$$

Tabel 3.2 Kriteria Keterampilan Proses

\begin{tabular}{ll}
\hline Presentase & Kategori Keterampilan \\
\hline $90 \%-100 \%$ & Sangat tinggi \\
\hline $75 \%-89 \%$ & Tinggi \\
\hline $55 \%-74 \%$ & Sedang \\
\hline $31 \%-54 \%$ & Rendah \\
\hline$<30 \%$ & Sangat rendah \\
\hline
\end{tabular}

Sumber: Anas Sudijono, 2017

\section{Uji Hipotesis}

Uji ini bertujuan untuk mengetahui ada tidaknya pengaruh model pembelajaran discovery learning melalui pembelajaran praktikum terhadap keterampilan proses peserta didik, adapun rumus sebagai berikut:

$$
r_{x y}=\frac{n \sum X Y-\left(\sum X\right)\left(\sum Y\right)}{\sqrt{\left\{n \sum X^{2}-\left(\sum X\right)^{2}\right\}} \sqrt{\left\{n \sum Y^{2}-\left(\sum Y\right)^{2}\right\}}}
$$

Sumber: Sugiyono, 2018

Keterangan :

$r_{\mathrm{xy}} \quad=$ koefisien korelasi antara variabel $\mathrm{x}$ dan variabel $\mathrm{y}$

$\mathrm{X} \quad=$ skor tiap item dari responden variabel $\mathrm{X}$

$\mathrm{Y} \quad=$ skor tiap item dari responden variabel $\mathrm{y}$

$\mathrm{XY} \quad=$ hasil kali variabel $\mathrm{x}$ dan $\mathrm{y}$ 
Jurnal Biologi dan Pembelajarannya, Vol 7 No 2, Oktober 2020. Pp: 36-43

e-ISSN: $2406-8659$

$\mathrm{n}$

$=$ jumlah responden

Analisis korelasi dapat dilanjutkan dengan menghitung koefisien determinasi, dengan cara menguadratkan koefisien yang ditemukan. Koefisien determinasi digunakan untuk mengetahui seberapa besar persentase pengarauh variabel independen terhadap variabel dependen. Koefisien korelasi mempunyai kriteria-kriteria sebagaimana ditunjukkan dalam Tabel 3.4.

Tabel 3.3 Pedoman Interprestasi Koefisien Korelasi

\begin{tabular}{lll}
\hline No. & Rentang & Kriteria \\
\hline 1 & $0,80-1,000$ & Sangat kuat \\
\hline 2 & $0,60-0,799$ & Kuat \\
\hline 3 & $0,40-0,599$ & Sedang \\
\hline 4 & $0,20-0,399$ & Rendah \\
\hline 5 & $0,00-0,199$ & Sangat rendah \\
\hline
\end{tabular}

Sumber: Sugiyono, 2018

Setelah memperoleh nilai rxy, selanjutnya menguji signifikansi korelasi dengan cara membandingkan antara nilai $r$ hasil korelasi product moment ( $r x y$ ) dengan nilai $r$ tabel ( $r t$ ) dalam taraf signifikansi $5 \%$ atau 0.05 .

kriteria pengujian jika rhitung < rtabel maka Ho diterima. Tetapi sebaliknya jika rhitung > rtabel maka $\mathrm{Ha}$ diterima dengan taraf signifikasinya ( ) adalah $0,05 \mathrm{dan} d \mathrm{k}=(\mathrm{n}-2)$ dengan $\mathrm{n}$ adalah banyak peserta didik.

Dimana:

Ho : tidak adanya pengaruh yang signifikan dari implementasi model discovery learning dengan praktikum Kingdom Plantae terhadap keterampilan proses peserta didik kelas X MIPA 2 di MA Unggulan KH.Abd. Wahab Hasbullah TambakBeras Jombang.

$\mathrm{Ha}$ : adanya pengaruh yang signifikan dari implementasi discovery learning dengan praktikum Kingdom Plantae terhadap keterampilan proses peserta didik kelas X MIPA 2 di MA Unggulan KH.Abd. Wahab Hasbullah TambakBeras Jombang.

Selanjutnya untuk menyatakan besar kecilnya sumbangan variabel $X$ terhadap $Y$ dapat ditentukan dengan rumus regresi sederhana (Sugiyono, 2018). Persamaan untuk model regresi sederhana adalah sebagai berikut:

$\mathrm{Y}=\mathrm{a}+\mathrm{Bx}$

Sumber: Sugiyono, 2018

Keterangan:

$\mathrm{Y}=$ Subyek dalam variabel dependen yang diperiksa

$\mathrm{a}=$ Harga $\mathrm{Y}$ ketika harga $\mathrm{X}=0$ (harga konstan)

$\mathrm{b}=$ Angka arah atau koefisien regresi, yang menunjukkan angka peningkatan ataupun penurunan variabel dependen yang didasarkan pada perubahan variabel independen. Bila (+) arah garis naik, dan bila (-) maka arah garis turun

$\mathrm{X}=$ Subyek pada variabel independen yang mempunyai nilai tertentu

Koefisien a dan $\mathrm{b}$ adalah koefisien regresi dimana nilai a dan $\mathrm{b}$ dapat dicari menggunakan persamaan berikut:

Sumber: Sugiyono,2018

$$
\begin{gathered}
a=\frac{\left(\sum Y\right)\left(\sum X^{2}\right)-\left(\sum X\right)\left(\sum Y^{2}\right)}{n \sum X^{2}-\left(\sum X^{2}\right)} \\
b=\frac{n\left(\sum X Y\right)-\left(\sum X\right)\left(\sum Y\right)}{n \sum X^{2}-\left(\sum X\right)^{2}}
\end{gathered}
$$

Keterangan:

$\mathrm{x}$ : skor tiap item dari responden variabel $\mathrm{x}$

$y$ : skor tiap item dari responden variabel y 
Jurnal Biologi dan Pembelajarannya, Vol 7 No 2, Oktober 2020. Pp: 36-43

e-ISSN: $2406-8659$

$x y$ : hasil kali variabel $x$ dan $y$

$\mathrm{n}$ : jumlah responden

\section{HASIL DAN PEMBAHASAN}

\section{Hasil Angket Keterlaksanaan Pembelajaran}

Berdasarkan hasil angket keterlaksanaan pembelajaran pada pertemuan (pretest) diperoleh nilai sebesar $100 \%$ dengan kategori Baik. Sedangkan untuk angket keterlaksanaan pembelajaran pada pertemuan (posttest) didapatkan nilai sebesar 100\% dengan kategori baik. Analisis keterlaksanaan proses pembelajaran secara umum, peneliti telah menerapkan model pembelajaran discovery learning dengan baik. Pada keterlaksanaan pembelajaran yang baik diharapkan kemampuan belajar peserta didik juga baik. Keterlaksanaan pembelajaran yang diamati meliputi keterlaksanaan sintak sesuai dengan model pembelajaran discovery learning. Dalam kegiatan pembelajaran tersebut, peserta didik dilibatkan untuk berperan aktif menguasai konsep pemahamannya sendiri. Penggunaan model pembelajaran discovery learning dapat membantu peserta didik pada proses pembelajaran, peserta didik lebih banyak berperan aktif dalam membangun pemahamannya sendiri. Hal ini sesuai yang dikemukakan [5] bahwa discovery learning adalah pembelajaran yang menitikberatkan pada mental intelektual para peserta didik dalam menyelesaikan berbagai masalah yang sedang dihadapi, sehingga dapat menemukan konsep atau gagasan yang kemudian diterapkan di lapangan. Penerapan model discovery learning sangat membantu dalam upaya guru meningkatkan kemampuan berfikir kreatif dan hasil belajar siswa [13].

\section{Hasil Angket Keterampilan Proses Peserta Didik} Tabel 4.1 Penilaian Keterampilan Proses Peserta Didik

\begin{tabular}{llcccc}
\hline \multirow{2}{*}{ No. } & \multicolumn{1}{c}{ Indikator } & \multicolumn{2}{c}{ Kriteria } & \multicolumn{2}{c}{ Kategori } \\
\cline { 3 - 5 } & & Pretest & Postest & Pretest & Postest \\
\hline 1 & Keterampilan Berkomunikasi & 50,30 & 75,15 & Sedang & Tinggi \\
\hline 2 & Keterampilan Menerapkan Konsep & 54,24 & 80,60 & Sedang & Tinggi \\
\hline 3 & $\begin{array}{l}\text { Keterampilan Menggunakan Alat dan } \\
\text { Bahan }\end{array}$ & 62,87 & 88,63 & Sedang & Tinggi \\
\hline 4 & Keterampilan Mengamati (observasi) & 54,34 & 80,80 & Sedang & Tinggi \\
\hline 5 & $\begin{array}{l}\text { Keterampilan Menafsirkan } \\
\text { (interpretasi) }\end{array}$ & 48,48 & 71,51 & Rendah & Sedang \\
\hline 6 & $\begin{array}{l}\text { Keterampilan Mengelompokkan } \\
\text { (klasifikasi) }\end{array}$ & 62,62 & 79,39 & Sedang & Tinggi \\
\hline
\end{tabular}

Secara keseluruhan menunjukkan kemampuan penguasaan keterampilan proses peserta didik setelah menggunakan model discovery learning lebih baik dibandingkan sebelum menggunakan model discovery learning. Hal ini juga diungkapkan oleh [4] bahwa model pembelajaran discovery learning adalah model mengajar yang mengatur pengajaran sedemikian rupa sehingga peserta didik memperoleh pengetahuan yang sebelumnya belum diketahuinya tidak melalui pemberitahuan, namun ditentukan sendiri. Berdasarkan seluruh rangkaian kegiatan tersebut, diketahui bahwa keterampilan proses merupakan salah satu upaya yang penting untuk memperoleh keberhasilan belajar peserta didik yang optimal [2].

\section{Pengujian Hipotesis}

\section{a. Uji Korelasi Product Moment}

Berdasarkan perhitungan uji Korelasi Product Moment, maka diperoleh hasil rhitung =0,801 dan rtabel $=0,345$ untuk $n=33$ dengan taraf signifikansi $5 \%$. Koefisien korelasi yang ditemukan sebesar 0,801 termasuk dalam kategori sangat kuat. Jadi koefisien determinasinya adalah $0,801^{2}=0,642$. Hal ini berarti pengaruh model discovery learning terhadap keterampilan proses peserta didik sebesar $64,2 \%$ dan sisanya 35,8\% ditentukan oleh faktor lain. Berdasarkan data tersebut maka Ha diterima, dengan demikian terdapat pengaruh yang signifikan model discovery learning dengan praktikum Kingdom Plantae terhadap keterampilan proses peserta didik. data tersebut menunjukkan adanya pengaruh yang signifikan pada implementasi model discovery learning dengan praktikum kingdom Plantae terhadap keterampilan proses peserta didik di MA Unggulan KH.Abd. Wahab Hasbullah TambakBeras Jombang. Dapat disimpulkan adanya peningkatan keterampilan proses pesera didik setelah diterapkannya model discovery learning, hal ini juga diungkapkan oleh [9] keterampilan proses peserta didik dengan menggunakan model discovery 
Jurnal Biologi dan Pembelajarannya, Vol 7 No 2, Oktober 2020. Pp: 36-43

e-ISSN: $2406-8659$

learning lebih baik dari pada keterampilan proses peserta didik yang tidak menggunakan model discovery learning.

\section{b. Regresi Sederhana}

Berdasarkan perhitungan uji regresi sederhana diperoleh persamaan regresi sebagai berikut:

$\mathrm{Y}=\mathrm{a}+\mathrm{bX}$

$Y=47,082+0,590 X$

Dari persamaan regresi diperoleh nilai konstanta regresi adalah 47,083 dan nilai koefisien regresi adalah 0,590 yang berarti jika penerapan model discovery learning bernilai (0) maka nilai keterampilan proses peserta didik 47,083. Dan setiap penerapan model discovery learning sebesar 1 kali pertemuan maka nilai keterampilan proses peserta didik akan meningkat sebesar 0,590. Jadi semakin sering model discovery learning diterapkan maka nilai keterampilan proses peserta didik semakin meningkat. Sebagai masukan bagi guru agar proses belajar mengajar dapat berjalan lebih efektif. Disarankan agar guru mempunyai kreatifitas dalam menciptakan suasana belajar yang dapat meningkatkan minat belajar siswa [14]

\section{SIMPULAN}

Berdasarkan analisis data hasil penelitian tentang implementasi model discovery learning dengan praktikum kingdom plantae untuk melatih keterampilan proses peserta didik di MA Unggulan KH.Abd. Wahab Hasbullah TambakBeras Jombang, maka dapat disimpulkan sebagai berikut:

1. Hasil keterlaksanaan pembelajaran model discovery learning dengan praktikum kingdom plantae didapati hasil sebesar $100 \%$ dengan kategori baik pada pertemuan pretest dan 100\% dengan kategori baik pada pertemuan posttest.

2. Hasil analisis keterampilan proses peserta didik diperoleh nilai rhitung $=0,801$ dan rtabel pada taraf signifikansi $5 \% \alpha=0,05$ sebesar 0,345, maka diperoleh rhitung > rtabel dengan demikian Ha diterima dan Ho ditolak, data tersebut menunjukkan adanya pengaruh yang signifikan pada implementasi model discovery learning dengan praktikum kingdom plantae terhadap keterampilan proses pesera didik kelas $\mathrm{X}$ MIPA 2 di MA Unggulan KH.Abd. Wahab Hasbullah TambakBeras Jombang.

\section{SARAN}

Berdasarkan hasil penelitian yang telah disimpulkan tersebut, maka dalam upaya meningkatkan keterampilan proses peseta didik perlu dikemukakan beberapa saran sebagai berikut:

1. Diharapkan guru dapat menggunakan model pembelajaran discovery learning dalam kegiatan praktikum untuk melatih keterampilan proses peserta didik.

2. Diharapkan guru yang dapat menguasai materi dengan baik sehingga interaktivitas pembelajaran lebih baik.

3. Bagi peneliti selanjutnya diharapkan dapat memahami dengan baik aspek-aspek keterampilan proses sains sehingga dapat memotivasi peserta didik lebih aktif dalam pembelajaran.

4. Bagi peneliti berikutnya disarankan agar benar-benar memahami langkah-langkah model discovery learning supaya tujuan penelitian dapat di capai dengan baik.

\section{UCAPAN TERIMA KASIH}

Penulis dapat mengucapkan terima kasih kepada Program Studi Pendidikan Biologi, Fakultas IImu Pendidikan, Universitas KH. A. Wahab Hasbullah yang telah memberikan dukungan selama proses penelitian

\section{DAFTAR PUSTAKA}

[1] Eka, W.S. 2015. Pengaruh Penerapan Model Pembelajaran Childen Learning in Science (CLS) dalam Pembelajaran IPA Terhadap Peningkatan Pemahaman Konsep dan Keterampilan Sains Siswa Sekolah Dasar. Tesis. Jakarta: Universitas Pendidikan Indoneisa. (Online). http://repository.upi.edu/20083/ , diakses 5 Maret 2020.

[2] Kurniawati, A. 2015. Analisis Keterampilan Proses Sains Peserta Didik Kelas XI Semester II MAN Tempel Tahun Ajaran 2012/2013 pada Pembelajaran Kimia dengan Model Learning Cycle 5E. Skripsi. Yogyakarta: Jurusan Pendidikan Kimia Fakultas Matematika Dan Ilmu Pengetahuan Alam Universitas Negeri Yogyakarta. (Online). https://eprints.uny.ac.id/30145/, diakses 20 Desember 2019.

[3] Hanafiah. 2012. Konsep Strategi Pembelajaran. Bandung: Refika Aditama.

[4] Cahyo. 2013. Panduan Aplikasi Teori Belajar. Jakarta: PT. Diva Press.

[5] Hamalik, O. 2011. Kurikulum dan Pembelajaran. Jakarta: Bumi Aksara. 
Jurnal Biologi dan Pembelajarannya, Vol 7 No 2, Oktober 2020. Pp: 36-43

e-ISSN: $2406-8659$

[6] Meishanti, Y.P.O., dan Baroroh, I. 2019. Strategi Belajar Mengajar Berorientasi K-13. Jombang: Fakultas Pertanian Universitas KH.A. Wahab Hasbullah.

[7] Wisudawati, W.A., Sulistyowati, E. 2014. Metodologi Pembelajaran IPA. Jakarta: PT Bumi Aksara.

[8] Handayani, B.T., Arifuddin, M., dan Misbah. 2017. Meningkatkan Keterampilam Proses Sains Melalui Model Guided Discovery Learning. Jurnal Ilmiah Fisika. Vol 1, No 3, (Online). https://ppip.ulm.ac.id/journals/index.php/iipf/article/view/1016, diakses 26 Oktober 2020.

[9] Rijal, C. 2018. Pengaruh Model Discovery Learning terhadap Keterampilan Proses Sains Siswa pada Materi Larutan Asam dan Basa di Kelas XI MAN 2 Aceh Utara. Skripsi. Fakultas Tarbiyah dan Keguruan Universitas Islam Negeri Ar-Raniry Darussalam Banda Aceh. (Online). https://repository.arraniry.ac.id/id/eprint/5396/1/Chairul\%20Rijal.pdf , diakses 20 Desember 2019.

[10] Fakinah, I. 2018. Penerapam Pembelajaran Praktikum terhadap Keterampilan Proses Sains Siswa pada Sub Materi Enzim di Kelas XII MAS Darus Aitami Aceh Selatan. Skripsi. Banda Aceh: Fakultas Tarbiyah dan Keguruan Universitas Islam Negeri Ar-Raniry Darussalam Banda Aceh. (Online). https://repository.arraniry.ac.id/id/eprint/4485/1/Indah\%20Fakinah\%20A.R.pdf , diakses 5 Januari 2020.

[11] Sugiyono. 2018. Metode Penelitian Kuantitatif, Kualitatif, dan R\&D. Bandung: Alfabeta.

[12] Anas, S. 2017. Pengantar Evaluasi Pendidikan. Jakarta: Raja Grafindo Persada.

[13] Niza, I., Ma'arif, IB., Meishanti, OPY. Discovery Learning Untuk Meningkatkan Kemampuan Berfikir Kreatif Dan Hasil Belajar Siswa Pada Konsep Keanekaragaman Hayati. Jurnal Eduscope (Online), Vol. 5, No. 02, http://ejournal.unwaha.ac.id/index.php/eduscope/article/view/390 diakses 6 November 2020

[14] Meishanti, OPY. 2019. Pengaruh Pemberian Kuis Terhadap Hasil Belajar Siswa Kelas VII Di SMPN Bandarkedungmulyo Jombang. Jurnal Eduscope (Online), Vol. 4, No. 01, http://ejournal.unwaha.ac.id/index.php/eduscope/article/view/380 diakses 6 November 2020 